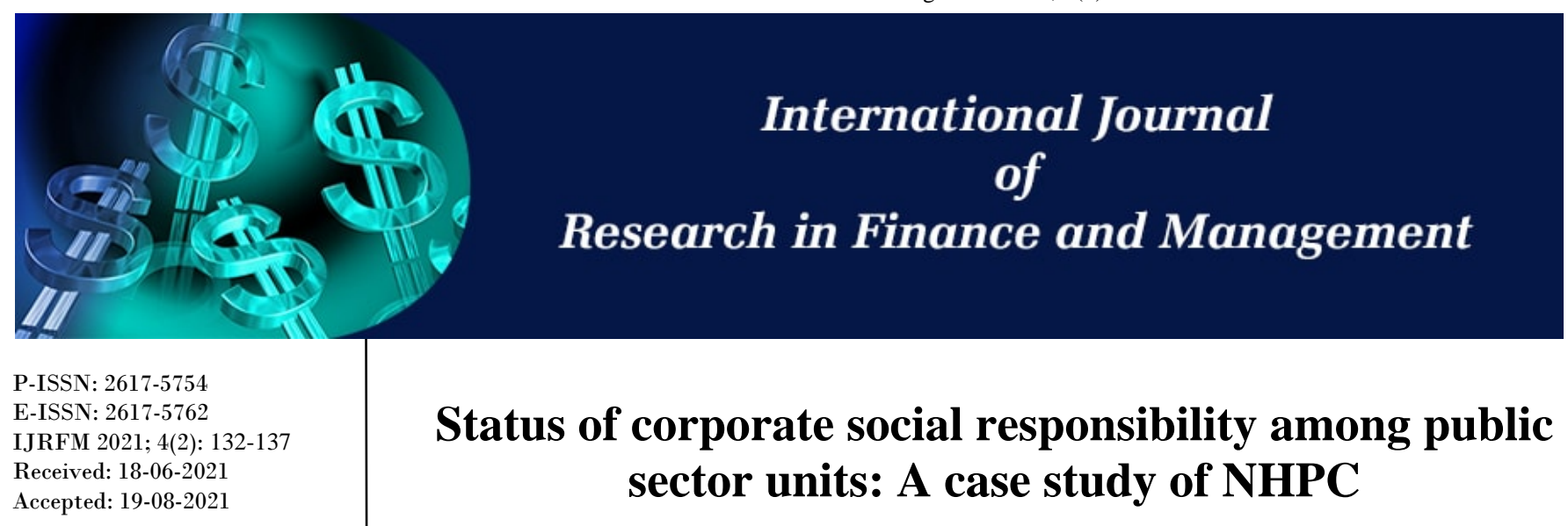

\section{Zulfikar Ali}

Research Scholar, Department of commerce and management, Himachal Pradesh University summer hill, Shimla, Himachal Pradesh, India

\section{Correspondence}

Zulfikar Ali

Research Scholar, Department of commerce and management, Himachal Pradesh University summer hill, Shimla, Himachal Pradesh, India

\section{Zulfikar Ali}

DOI: $\underline{\text { https://doi.org/10.33545/26175754.2021.v4.i2a.118 }}$

\begin{abstract}
The concept of CSR has a long and wide-ranging history. It is a concept whereby companies decide voluntarily to contribute to the betterment of society and the environment. The companies' act 2013 which mandates companies to spend on CSR activities as a result the term corporate social responsibility has gained worldwide attention and has achieved a new resonance in the global economy. This shows how CSR transited from being a voluntary, to a mainstream activity of business. Because of this dynamic nature of CSR it becomes very relevant to study on some of the unexplored dimensions of CSR and bring something valuable and add something to the existing literature of CSR. Present study highlights the CSR initiatives of hydro power company in India. The study focused on CSR activities carried out by NHPC over a period of five years. The study found that NHPC limited were more focused on their CSR activities and working for the welfare of society but still a lot to do for overcoming the problems.
\end{abstract}

Keywords: Corporate social responsibility, NHPC, hydro power, companies act 2013

\section{Introduction}

The voluntary compliance of social and environmental responsibility of companies is called corporate social responsibility. It refers to a concept whereby companies decide voluntarily to contribute to the betterment of society and the environment. It is a concept whereby companies integrate social and environmental concerns into their business operations and their interaction with their stakeholders on a voluntary basis. It is represented by contributions undertaken by companies to society through its business activities and social investment. CSR is also linked with the principal of sustainability, which argues that enterprises should make decisions based not only on financial factors such as profits or dividends, but also based on the immediate and long term social and environmental consequences of their activities. The term corporate social responsibility has recently gained worldwide attention and has achieved a new resonance in the global economy. Debates are still going on as what is the range of social responsibility, what constitutes the social responsibility of business and when a corporation can be termed as truly socially responsible. On September 2013, Indian government has mandated CSR activities for corporate firms which are earning profits as per company's act-2013 and they needed to spend 2 percent of their annual profit on CSR activities. A progress report on the activities undertaken is to be included in the annual report and signed by a director of the company (KPMG, 2014) ${ }^{[7]}$. The purpose of the act was to improve the company's climate to contribute positively to society and encourage the positive contribution enterprises can make to economic and social progress.

\section{Review of Literature}

Acharyya \& Agarwala, (2020) ${ }^{[1]}$ did a study on "Relationship between CSR motivations and corporate social performance: a study in the power industry in India” purpose of the article is to understand the reasons for engaging in CSR activities by the organizations. The study also focused on examines the relationship between CSR motivations and corporate social performance (CSP). Both primary and secondary data used to conduct the study. Finding of the study shows that the CSP score was significantly different among the public and private sectors firms. 
The private sector firm had a higher CSP level than the public sector undertaking and also the private sector firm was found to be significantly higher with respect to CSR motivations when compared with the public sector firms. (Pashupatimath \& K, 2020) ${ }^{[12]}$ Did a study on Corporate Social Responsibility Initiatives: Issues and Challenges in Indian Context. Secondary data was used for the purpose of the study. The researcher found that there are various problems companies faced for the effectiveness of CSR. Challenges of Corporate Social Responsibility which support my study are that there is lack of community participation in CSR activities and lack of consensus on implementing CSR projects. Rai, (2019) ${ }^{[13]}$ a descriptive study on an analysis on CSR in India. The main aims of this paper are to understand the concept of CSR and to analyse its changing trends. Researcher tried to highlight challenges facing while implementing CSR and to provide suggestions to accelerate the CSR initiatives. Research is done systematically by using secondary data. Researcher found that there is a need for creation of awareness about CSR amongst the general public to make CSR initiatives more effective. (Kakade, 2019) [5] Undertake a study on comparative study of corporate social responsibility practices in India, aim of the research is to explore the position of Indian companies regarding corporate social responsibility. Study used convenience sampling technique to collect responses through structured questionnaire. Funding suggest that CSR is not considered as a basic business framework in every company. Mukherjee et al., (2018) ${ }^{[10]}$ made an investigation on "Mandatory corporate social responsibility, the Indian experience”. In this study they concentrated on the impact of making CSR expenditure mandatory to corporates and to determine the relationship between profitability and CSR spending by comparing before and after the introduction of legislation. In this study they found that the impact of mandatory CSR spending had the wrong effect in term of volume of CSR expenditure and also the activities to which it has been directed and in particular they found that there was structural break in the relationship between CSR spending and corporate profitability due to introduction of the legislation of mandatory CSR spending. They summarised that grater care must be taken when implementing mandatory CSR if it is to be effective. (Ranjan \& Tiwary, 2017) ${ }^{[14]}$ Conducted "A Comparative Study of CSR in Selected Indian Public \& Private Sector Organisations in Globalisation Period: A Research Finding.” The study has done to recognized the important activities as well as impact of CSR in the country and study taken both public and private organisation in consideration. Different problems and positive impacts have been analysed and interpreted in the study. Both primary and secondary data had been used to conduct this study. Researcher found that health, education, games and sports, sanitation, and environment protection are the thrust area for CSR activities of selected organisation. Maximum respondents propound that there is lack of community participation in CSR activities. The researcher suggested that the community participation should be incorporated in CSR activities. (Saxena, 2016) ${ }^{[15]}$ did a study on issues and challenges of CSR in Indian context. In India the concept of corporate responsibilities is in existence since ancient times even though CSR policy is still in a nascent stage. In her study researcher found that there is a need for creation of awareness about CSR amongst the general public to make CSR initiatives more effective. Nair, (2015) ${ }^{[11]}$ analysed "CSR In The Indian Scenario" in which he tried to understand concept of CSR, its evolution in India, the benefits of CSR, the current CSR practices of eminent Indian companies and the deceptive claims companies make of being good corporate citizens. In conclusion he stated that in India many companies have taken up sincere initiative. However, they still need to go a long way in taking up CSR as part of their organization strategies. K and Bhushan. B, (2015) [4] "A Study on Corporate Social Responsibility Initiatives of Wipro Ltd.”. Their paper focuses on the fundamentals of CSR and specifically emphasizes about the CSR activities being carried out by Wipro Company to know how Wipro Ltd has fulfilled its responsibility towards all stakeholders; what specific activities, programs and strategies it has set, devised and implemented. Researcher used secondary data from different sources to conduct the study. By looking at the various CSR initiatives of Wipro Ltd, it is very much visible that Wipro has done a lot to the upliftment of the society particularly in the field of education, primary health, environment and Disaster Rehabilitation. Anil Dhaneshwar and Pooja Pandey, (2015) ${ }^{[2]}$ assessed the status of CSR among Indian public sector undertakings in the Oil and Power sector. This paper attempted to understand the initiatives under the mandatory rules of CSR and they tried to draw and assimilate possible suggestions and observations. Some relevant suggestions which support my research are that there is a need to document and refer the impact and findings of the CSR activities initiated by the PSUs. Researcher suggested that the companies need to join hands with several stakeholders including the localgovernment, NGOs, other corporate with the same objectives, expert bodies, community representatives, social-researchers etc. This will strengthen the premise of the CSR operations and bring sustainability to the efforts. Loura, (2014) ${ }^{[9]}$ conducted a study of selected PSU's to understand the CSR initiatives being taken by them for rural development and also to evaluate the impacts of CSR actions on targeted population. The study was done by analysed the secondary data. The study concluded that CSR initiative being implemented by the Indian PSU's for rural development have a positive impacted in overall development of society. Kumar, (2013) ${ }^{[8]}$ conducted a study on corporate social responsibility. The main purpose of the study is to analyse the CSR activities carried out by Indian private and public sector companies. In the private sector, he analysed the CSR activities of Reliance Industries Ltd. (RIL) and in the public sector, he analysed the CSR activities of Oil and Natural Gas Corporation (ONGC). The study is based on secondary data taken from different sources and the study adopted a descriptive and analytical research design. His findings revealed that though the Indian public and private firms are making efforts in the CSR areas, still there is a requirement of more emphasis on CSR. Analyses also showed that there is a significant difference in the CSR practices of RIL and ONGC firms as the CSR budget of ONGC is more than RIL during 2009-10, 2010-11 and 2011-12 and average CSR score of ONGC is more than that of RIL during 2009 to 2013 . Kesavan, (2012) ${ }^{[6]}$ did a 
study on corporate social responsibility. In this article researcher highlighted the CSR practices of Indian PSUs. After evaluating the CSR performance of some companies he concluded, Corporates in India both public as well as private organizations are striving to improve the public image of business. Most of these organizations believe in being and becoming good corporate citizens. From the facts, it can be seen that the value of giving back to the society is very vital for their success. CSR is no longer mere philanthropy; it is an indispensable one for sustainable development. Hence these organizations have developed a multi-dimensional framework for fulfilling its social responsibility. Berad, (2011) ${ }^{[3]}$ did the study on "Corporate Social Responsibility-Issues and Challenges in India” by analysing the findings and reviewing of the issues and challenges faced by companies while implementing corporate social responsibility activities in India. Researcher found that corporate social responsibility is at nascent stage in India. A large number of companies are undertaking these activities superficially and promoting/highlighting the activities in media. Shah and Bhaskar, (2010) ${ }^{[16]}$ the aim of paper is to highlight CSR initiatives undertaken by BPCL. The data collection for this article had been done by the authors through interview and through information available in the public domain. From this study it is found that BPCL undertaken many CSR initiative to make the local communities self-reliant so that they can earn their livelihood for eternal help and support.

\section{Significance of the study}

As everyone knows that, PSUs have a very prominent role in CSR as they are the pillar of the economy and their actions provide a direction for the conduct of CSR for the rest of business units. Works are being done on CSR by different scholars to improve and add something new to the existing knowledge. However, not much such study has been conducted over hydro power companies yet. Therefore, the planned work will be of great significance. The results will be going to be useful for researchers, corporate sector and government and so on. The research covers CSR initiatives by NHPC over a period of five years; hence it's extremely useful in today's context.

\section{Objectives of Study}

The purpose of this article is to analysis of CSR activity of NHPC over a period of five years and to bring out its outcomes over the period of time.

The main objectives of this study are:

To study in details the CSR activities carried out by NHPC. To analyse the amount spent over a period of five years.

\section{Research Methodology}

To conduct this study secondary data is used. Exhaustive literature survey regarding the topic and related concepts has been done.

Data Source: Data on CSR have been collected from various sources including Annual Reports of the company, books, research papers, newspapers, magazines, and websites is used for the purpose of study.

Time period: The CSR activities have been studied for five consecutive years starting from 2014-15 to 2018-19.

\section{About the organisation}

With the vision, to be a global leading organisation for sustainable development of clean power through competent, responsible and innovative values, NHPC limited was incorporated in the year 1975 as a private limited company under the name National hydroelectric power corporation. In 1986 the company was converted into a public limited company. The objective of organisation is to plan, promote and organize an integrated and efficient development of power in all aspects and including planning, design and construction, erection, generation, transmission, distribution and sale of Hydroelectric Power and other business.

Presently, NHPC limited is a Mini Ratna Category-1 Enterprise of the government of India. The company has become the largest organisation in the field of hydropower development in the country. NHPC limited as on date has an installation base of 7071.2 MW from 24 power stations in different parts of India as well as abroad.

\section{CSR initiatives by NHPC limited.}

The concept of Corporate Social Responsibility (CSR) is gaining in prominence to play a valuable role in the development of several underdeveloped regions of the country. NHPC claiming that they conducting its business in a socially responsible way to win the trust and confidence of all stakeholders. To guide and to supervise of its CSR initiatives and to ensure implementation of the policy and commitment in conformity with the enactment of Section 135 of the Companies Act, 2013, NHPC has a separate Committee of Directors on CSR and the company has welldefined CSR policy approved by its board. CSR Vision of company is to contribute to sustainable development and inclusive growth while taking care of People, Planet and profit. CSR mission of NHPC is to become entity committed to improving the quality of life of the society at large and to create and develop facilities for the local communities in which business is operated.

\section{The CSR focus areas of NHPC are}

Education including vocational courses, Health Care, Swachh Bharat Abhiyan \& Swachh Vidyalaya Abhiyan, Infrastructure support near NHPC operational areas, Environment protection, ecological conservation, promotion, Women's Empowerment, Girl Child Development, Water Management including ground water recharge, Initiatives for physically and mentally challenged, Sponsorship of seminars, conferences, workshops etc.

Promoting Sports/sports persons; supporting agencies promoting sports / sports persons.

NHPC is conducting its business in a socially responsible manner by maintaining high levels of organizational integrity and ethical behaviour conforming to the expected standards of transparency in reporting and disclosure. NHPC demonstrates its concern for social welfare by adoption of best practices and effective operational strategy to win the trust and confidence of its stakeholders. Schedule VII wise CSR expenditure during the period of 2014-15 to 2018-19 are enlisted below.

\section{Health and Sanitation}


To improve health facilities in different part of the country through CSR, NHPC conducted various programs, organizing camps, distribution of free medicine, improvement of infrastructures of hospital, medical equipment etc. and also constructed toilet in schools, maternity centres at village etc. For improvement of sanitation facilities.

\section{Education}

In field of education NHPC leads from the front through its CSR. Numerous work had been done in education sector such as construction of class room, renovation works at school, distribution of scholarship to school and ITI, skill development program etc.

\section{Rural Development}

As a social responsibility NHPC through CSR various development activities are undertaken to improve standard of living of people living in rural areas of various power stations. some of the major activities are, taken up various rural development programme and provide basic infrastructure facilities such as establishment of community centre, water supply, roads etc. the company had also undertaken the construction activities of bridge, rain shelter etc. Company is also worked to educate farmers for development of agriculture, organic cultivation and other advance method of farming.

\section{Environment and sustainability}

As a social responsibility for environment and sustainability NHPC conducted various CSR activities for-instance development of bio-diversity parks, plantation, irrigation canals, solar street lights establishment of food processing plants etc. The company is also committed to environment sustainability conservation of natural resources, maintaining quality of air, water and soil.

\section{Women Empowerment and senior citizen}

A number of CSR initiatives are taken by NHPC for women empowerment and created facilities for senior citizens. Company imparting skill development training and providing machines to promote self-empowerment for women.

\section{Swachh Bharat Abhiyan (SBA) + Swachh vidyalaya Abhiyan (SVA)}

It is the area which is given the most importance by the company approx. 34\% of CSR fund of last five years is spend in this area. NHPC conducted numerous public health and sanitation activities had been undertaken as CSR activities under SBA \& SVA company provide drinking water facilities, basic sanitation facilities in public area, construction or installation of water supply lines and sanitation in villages, construction of toilets in schools, market places, water supply for schools etc.

\section{CSR capacity building and other Activities}

Being a socially responsible company NHPC had also contribute a lot to promote arts, culture and traditional sports by creating social awareness through organizing various awareness programmes and meeting with stake holder.

\section{Analysis and Discussion Corporate Social Responsibility status in NHPC Limited:}

As per the Act NHPC required to spend $2 \%$ of their average net profit of last three financial years, calculated as per section 198 of companies act 2013.

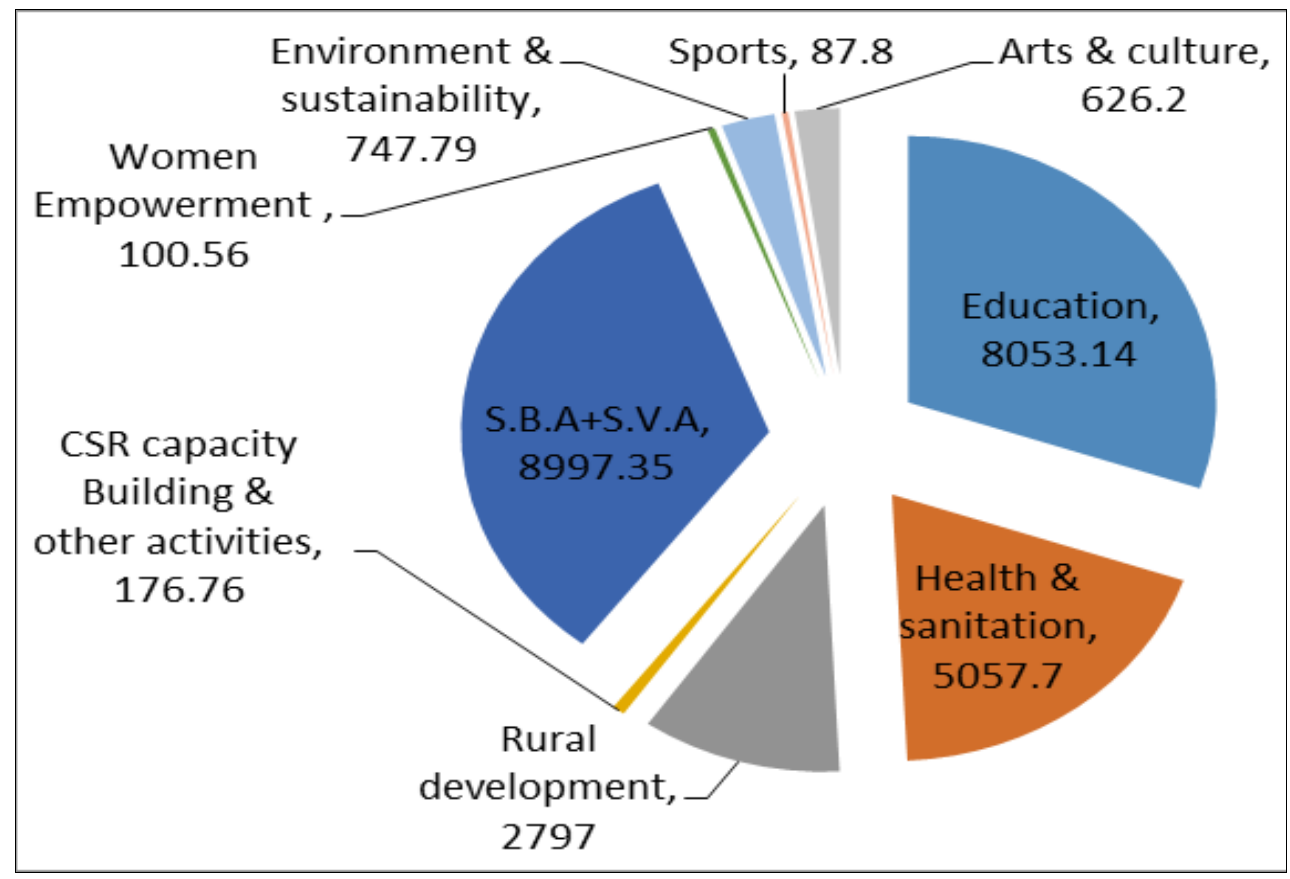

Source: extracted and consolidated from CSR report of NHPC

Graph 1: Showing Sector wise Expenditure during FY 2014-15 to 2018-19. 
Table 1: Sector Wise Expenditure on CSR \& Sustainability during FY 2014-15 to 2018-19. (Amount in lakh)

\begin{tabular}{|c|c|c|c|c|c|c|}
\hline Sector & $\mathbf{2 0 1 4 - 1 5}$ & $\mathbf{2 0 0 1 5 - 1 6}$ & $\mathbf{2 0 1 6 - 1 7}$ & $\mathbf{2 0 1 7 - 1 8}$ & $\mathbf{2 0 1 8}-19$ & Total \\
\hline Education & 1142.57 & 469.05 & 5036.39 & 590.38 & 814.75 & 8053.14 \\
\hline Health \& sanitation & 281.49 & 507.42 & 1530.55 & 1890.87 & 847.37 & 5057.7 \\
\hline Rural development & 980.64 & 253.20 & 551.45 & 373.25 & 638.46 & 2797 \\
\hline CSR capacity Building \& other activities & 15.33 & 2.71 & 131.73 & 16.13 & 10.86 & 176.76 \\
\hline S.B.A+S.V.A & 2308.23 & 5945.19 & 253.18 & 279.23 & 211.52 & 8997.35 \\
\hline Women Empowerment & 58.44 & 1.49 & 18.37 & 0.97 & 21.29 & 100.56 \\
\hline Environment \& sustainability & 354.55 & 57 & 60.29 & 151.30 & 124.65 & 747.79 \\
\hline Sports & 47.04 & 6.54 & - & 5.59 & 28.63 & 87.8 \\
\hline Arts \& culture & 35.65 & 24.95 & - & 546.99 & 18.61 & 626.2 \\
\hline Total(crore) & 5223.94 & 7267.55 & 7581.96 & 3854.71 & 2716.14 & 26644.3 \\
\hline
\end{tabular}

Source: extracted and consolidated from CSR report of NHPC

The above table and graph shows that NHPC contribute around 34 percent on SBA + SVA and Education received around 33 percent of its total expenditure on CSR. This is followed by health and rural development, which received around 25 percent and 16 percent respectively. This paper finds that NHPC disclosed all information on expenditure and the deployment to various projects running and initiated in the said financial year. The analysis is based on the total expenditure done by NHPC during the five year of post mandatory period.

Table 2: Showing Mandatory Fund Allocation and Actual Expenditure on CSR during 2014-15 to 2018-19.

\begin{tabular}{|c|c|c|}
\hline Financial Year & Mandatory Fund Allocation & Actual Expenditure \\
\hline $2014-15$ & 4764 & 5223.94 \\
\hline $2015-16$ & 4328 & 7267.55 \\
\hline $2016-17$ & 4423 & 7581.87 \\
\hline $2017-18$ & 5952 & 3855 \\
\hline $2018-19$ & 6003 & 2716 \\
\hline
\end{tabular}

Source: extracted and consolidated from CSR report of NHPC

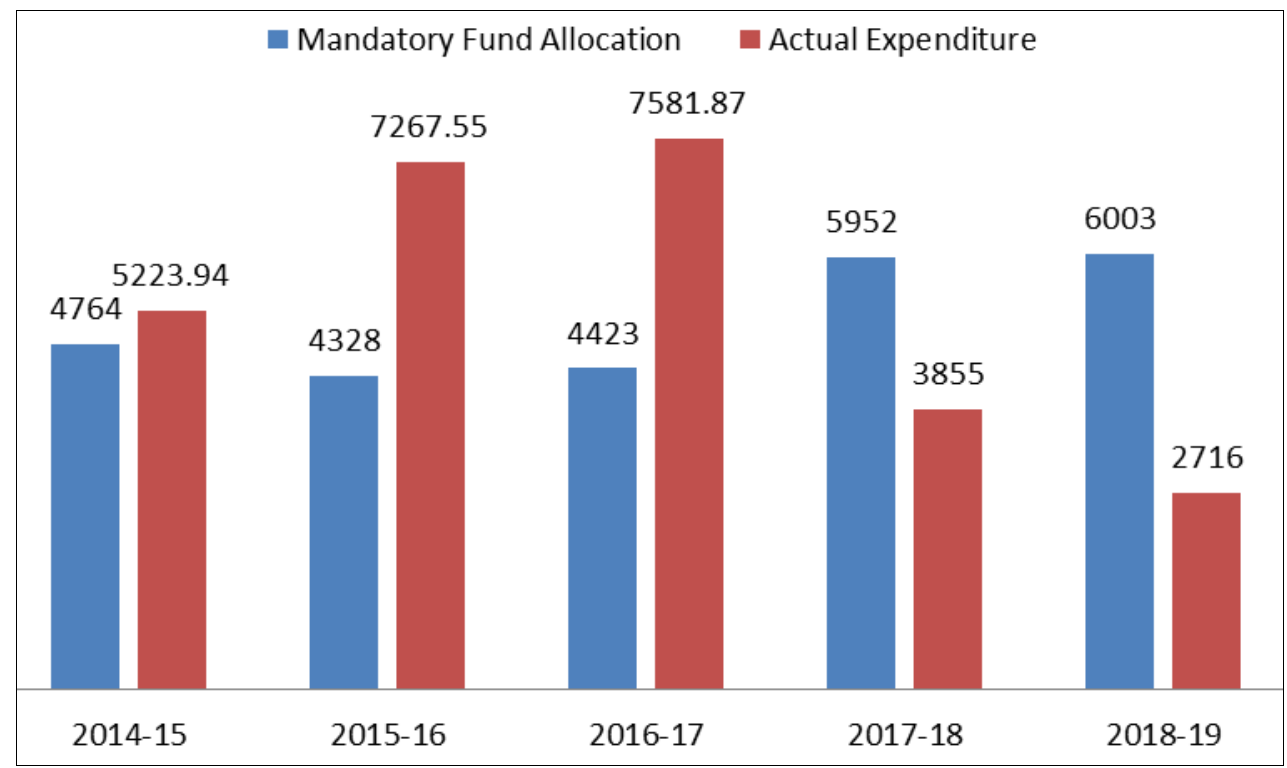

Source: extracted and consolidated from CSR report of NHPC

Graph 2: Showing Mandatory Fund Allocation and Actual Expenditure on CSR during 2014-15 to 2018-19

The table and graph showing above shows the mandatory fund allocation and actual expenditure on CSR during 201415 to 2018-19 by NHPC. The data compares the CSR spending for five consecutive years 2014 -15 to 2018 -19 post amendment of Company's Act. In 2014-15, NHPC was qualified the $2 \%$ criteria based on their three years average profit for CSR expenditure. The total mandatory allocation of NHPC in 2014-15 was INR 4764 lakh. Which increased by 1239 lakh INR to 6003 INR in 2018 -19. The data shows the actual spending on CSR was more than the mandatory allocation of CSR funds in the first three years. Though the prescribed spending showed an upward trend. The spending details show there is optimistic upward trend in actual spending on CSR activities in first three year where the actual spending has gone up. Interestingly the CSR expenditure has been reduced drastically in next two year from 7581.87 lakh INR in 2016-17 to 2716 lakh INR on 2018-19.

Here it is important to note that the cumulative Actual expenditure by NHPC from 2014-15 to 2018-19 is INR 26644.3lakh and the sum total of mandatory fund allocation for the same period is INR-25,470 lakh. This means that 
NHPC total actual expenditure in five year of post mandatory period is grater then the mandatory fund allocation in the same period.

\section{Suggestions}

- Areas covered under CSR activities are limited by the company act 2013. It is found that the company spend huge amount of CSR fund in the field of education, health, SBA \& SVA in which government also spend a lot. So it should be spread and well defined by government to consider other areas as well.

- Company spend each year approx. $80 \%$ of their CSR fund in the area in which company's operations take place, but special CSR activities should be incorporated for remote as well as for rural areas. So that mass population could avail benefits from CSR activities.

- $\quad$ There is shrinking role of government regarding CSR activities. So it is suggested that the role of government regarding CSR should be more effective.

- CSR activities should be more transparent, so it is suggested that government should monitored the CSR activities of companies.

\section{Conclusion}

The Companies bill is a good initiative on the part of the government. As per the act, companies with the net worth of INR 500 crore or more, or turnover INR1000 crore or more, or net profit INR5 crore or more, during the immediate preceding financial year are required to spend $2 \%$ of their average net profit of presiding three year on CSR activities. NHPC fall within the ambit of the definition and therefore required to spend $2 \%$ of their profit on CSR activities. By looking at the various CSR initiatives of NHPC, it is very much visible that NHPC had done a lot to the society particularly in the field of education, primary health, environment and SVA\&SBA. The analysed data reveals that though the NHPC making efforts in the CSR areas but still there is a requirement of more emphasis on CSR and in conclusion it is found that grater care must be taken for mandatory CSR if it is to be effective.

\section{Acknowledgements}

First of all, I would like to express my deepest gratitude to my research guide Prof. Kuldeep Kumar Atari for his constant guidance and encouragement for this work. I also take the privilege to record my deepest appreciation and heartiest thanks to Dr. Mohd Sharif and Dr. Virender Kaushal for inspiring me in accomplishing this paper.

\section{References}

1. Acharyya M, Agarwala T. Relationship between CSR motivations and corporate social performance: A study in the power industry in India. Employee Relations, 2020. https://doi.org/10.1108/ER-01-2019-0091

2. Anil Dhaneshwar, Pooja Pandey. Status of Corporate Social Responsibility among PSUs in India (A study of the CSR scenario of Oil and Power sector PSUs). Managing Director at Genesis Management and Market Research, 2015. https://doi.org/10.13140/RG.2.1.4368.0240

3. Berad NR. Corporate Social Responsibility-Issues and Challenges in India. International Conference on
Technology and Business Management, 2011, 101-108. http://www.nhpcindia.com

4. KS, Bhushan BB. "A Study on Corporate Social Responsibility Initiatives of Wipro Ltd" "A Study on Corporate Social Responsibility Initiatives of Wipro Ltd.” ELK Asia Pacific Journals, 2015.

5. Kakade DKS. A Comparative Study of Corporate Social Responsibility Practices in India. RESEARCH REVIEW International Journal of Multidisciplinary, 2019. https://doi.org/10.13140/RG.2.2.28202.47047

6. Kesavan DS. Corporate Social Responsibility (CSR). International Journal of Innovative Research and Development. 2012;1(3):121-133.

7. KPMG. Corporate sustainability: Drivers and enablers. 2014.

8. Kumar MR. Corporate Social Responsibility (Analysis of Select Indian Private and Public sector companies). International Journal of Innovative Research in Science \& Engineering. 2013.

9. Loura J. Corporate Social Responsibility-A Case Study of Select PSU's Role in Rural Development. International Journal of Management and Social Sciences Research. 2014;3(2):53-57.

10. Mukherjee A, Bird R, Duppati G. Mandatory Corporate Social Responsibility: The Indian experience. Journal of Contemporary Accounting and Economics. 2018;14(3):254-265. https://doi.org/10.1016/j.jcae.2018.06.002

11. Nair MT. Csr in the Indian scenario. International Journal of Management and Commerce Innovations. 2015;3(2):493-499.

12. Pashupatimath KDS A. Corporate social responsibility: Its roles and challenges in Indian context. Mukt Shabd Journal. 2020;9(5):5721.

13. Rai DS. An analysis of corporate social responsibility in India. Research Review International Journal of Multidisciplinary. 2019;04(01):2226-2230.

14. Ranjan R, Tiwary PK. A Comparative Study of CSR in Selected Indian Public \& Private Sector Organisations in Globalisation Period: A Research Finding. International Journal of Emerging Research in Management and Technology. 2017;6(6):270. https://doi.org/10.23956/ijermt.v6i6.281

15. Saxena CAN. Corporate Social Responsibility: Issues \& Challenges. International Journal of Research and Scientific Innovation (IJRSI), 2016, 41-46.

16. Shah S, Bhaskar AS. Corporate Social Responsibility in an Indian Public Sector Organization: A Case Study of Bharat Petroleum Corporation Ltd. Journal of Human Values. 2010;2(2010):143-156. https://doi.org/10.1177/097168581001600202 